\title{
Apresentação de um novo dispositivo para mensuração do ângulo de torção da perna
}

\author{
Evaluation of a new device for measuring the leg torsion angle
}

Sérgio José Lawand ${ }^{1}$, Amâncio Ramalho JúnIor ${ }^{2}$, Ricardo LUiz Smith ${ }^{3}$

\section{RESUMO}

Variações rotacionais dos membros inferiores no plano transverso são responsáveis por um grande número de doenças que acometem crianças e indivíduos adultos. Nas crianças, podemos citar como exemplo, um quadro comum, a marcha com os "pés para dentro" ("toeing in") e nos indivíduos adultos, a incapacitante artrose degenerativa dos joelhos.

Enquanto as alterações ósseas localizadas no plano transverso são difíceis de serem avaliadas, as deformidades presentes nos planos frontal e sagital podem ser avaliadas facilmente através, por exemplo, de simples radiografias.

Neste contexto, dentre os métodos disponíveis para o estudo rotacional da perna, não há procedimento clínico ou de imagem que reúna as características de precisão, praticidade e baixo custo.

Com o intuito de preencher esta lacuna, os autores apresentam um dispositivo para aferição clínica indireta do ângulo de torção da perna para indivíduos adultos e crianças. Neste artigo, procedeu-se a avaliação e a análise de 40 membros inferiores de cadáveres adultos humanos.

Descritores: Tíbia; Antropometria; Marcha.

\section{INTRODUÇÃO}

O mau alinhamento rotacional das extremidades inferiores na infância é uma alteração freqüente que pode, na vida adulta, atuar como fator causal de diversas doenças do aparelho locomotor caso não seja diagnosticado e tratado de forma adequada $(1,8,9,10,13,15)$.

A torção da perna é o resultado da diferença entre o eixo de flexão da articulação fêmoro-tibial e o eixo de flexão tíbio-talar no plano transversal e está sujeita á variações conforme a idade, sexo, características anatômicas e populacionais assim como, a outras doenças ósteo-articulares que possam estar presentes ${ }^{(1,4,13)}$.

\section{SUMMARY}

Variations and deformities of lower limbs invo/ving rotation in the transverse plane are associated with many clinical problems, ranging from harmless in-toing in children to disabling degenerative osteoarthritis of the knee in adult patients.

While the bone alterations located in the transverse plane are difficult to be assessed, the frontal and sagittal deformities can be easily assessed, for instance, with the conventional radiographies.

In this context, among the most available methods for the leg rotational study, there is not any clinical or image procedure which is more accurate, practical or with low cost.

In order to solve this problem, the authors present a new device to indirect clinical standard of the leg torsion angle in adults and children. In this study, 40 lower limbs from human cadavers were assessed and analyzed.

Key words: Tibia; Anthropometry; Gait

\section{INTRODUCTION}

The bad alignment of the lower limbs rotation during childhood is a frequent alteration that at adult life can be the cause of several clinical locomotor problems if not appropriately diagnosed and treated $(1,8,9,10,13,15)$.

The leg torsion is the consequence of a difference between tibiofemoral joint flexion and tibiotalar axis flexion in the transverse plane, and it can be different according to the age, sex, anatomical and populational characteristics and osteoarticular clinical problems ${ }^{(1,4,13)}$.

The leg torsion angle assessment has fundamental impor-
Trabalho desenvolvido na Disciplina de Anatomia Descritiva e Topográfica do Departamento de Morfologia da UNIFESP/ EPM.

1 - Médico Especialista em Ortopedia e Traumatologia pela SBOT 2 - Médico Especialista em Ortopedia e Traumatologia pela SBOT; Ortopedista do Hospital Israelita Albert Einstein 3 - Professor Titular, Livre- Docente, Chefe da Disciplina de Anatomia Descritiva e Topográfica do Departamento de Morfologia da UNIFESP/ EPM

Endereço para correspondência: UNIFESP/ EPM - Rua Botucatu, 740 Edifício Leitão da Cunha, térreo - Disciplina de Anatomia Descritiva e Topográfica - cep: 04023-900, São Paulo- SP.

email: amancio@einstein.br
Work developed in the Descriptive and Topography Anatomy Discipline of the morphological department.

1 - Doctor Orthopedics and Traumatology for SBOT

2 - Doctor Orthopedics and Traumatology for SBOT; Orthopedist of Albert Einstein Israelita Hospital

3 - Chairman, Full Professor, Head of the Descriptive and Topographic Anatomy of the Morphological Department of UNIFESP/EPM

Address: UNIFESP/ EPM - Rua Botucatu, 740 Edifício Leão da Cunha, térreo - Disciplina de Anatomia Descritiva e Topográfica Cep: 04023-900, São Paulo e-mail: amancio@einstein.br 
A avaliação do ângulo de torção da perna tem importância fundamental na detecção precoce e no prognóstico de diversas doenças do aparelho locomotor, porém os métodos clínicos antropométricos descritos até hoje, nos fornecem valores que variam de 0 á $45^{\circ}$, o que levanta dúvidas quanto á precisão $(2,10,13,15)$.

Por outro lado, o estudo da torção tibial através de radiografias simples é complexo e pouco prático ${ }^{(5,7,13)}$. Como alternativa, o método de avaliação por tomografia computadorizada tem se mostrado promissor até o momento, mas apresenta como pontos desfavoráveis, a falta de padronização e o alto custo inviabilizando o seguimento do doente em muitos casos.

Apresentamos neste artigo, um dispositivo clínico antropométrico que determina o valor angular de torção a perna de maneira indireta, através de cálculo trigonométrico. O objetivo final é contribuir para a praticidade da avaliação do ângulo de torção da perna através de um método simples, de fácil reprodução facilitando assim o seguimento do paciente.

\section{MATERIAL E MÉTODOS}

O dispositivo consiste-se de um aparelho mecânico que avalia variáveis antropométricas nos planos frontal e sagital da perna para determinação indireta do seu ângulo de torção. O aparelho foi montado utilizando-se materiais de baixo custo e facilmente acessíveis, como placas de acrílico, três réguas, cola, uma placa de madeira e alguns parafusos

As peças anatômicas avaliadas, pertenciam ao Laboratório de Anatomia da Disciplina de Anatomia Descritiva e Topográfica do Departamento de Morfologia da Universidade Federal de São Paulo/ Escola Paulista de Medicina. O projeto de pesquisa foi aprovado pelo Comitê de Ética e Pesquisa da mesma instituição cumprindo a resolução 196/96 do Conselho Nacional de Saúde.

Os 40 membros inferiores estudados estavam desarticulados de seus respectivos cadáveres humanos adultos e fixados com formaldeído. Vinte e cinco membros encontravam-se desarticulados a partir do fêmur, os outros 15 restantes a partir da hemi pelve. O lado avaliado não foi considerado na avaliação dos resultados.

As variáveis antropométricas estudadas foram: 1- à distância intermaleolar, determinada medindo-se à distância entre o centro dos maléolos lateral e medial (D); 2- à distância entre o centro do maléolo medial e o anteparo posterior do dispositivo (M); 3- à distância entre o centro do maléolo lateral e o anteparo posterior do dispositivo (L).

O dispositivo apresentava : um anteparo principal para apoio da face posterior da perna; um segundo anteparo menor de madeira, ortogonalmente acoplado na extremidade proximal do primeiro, para o apoio da coxa; três réguas adaptadas na extremidade distal do anteparo principal. De acordo com esta montagem, o membro inferior estudado era posicionado com o joelho fletido a $90^{\circ}$ estando os côndilos tibiais e a face posterior do calcâneo em repouso sobre o anteparo principal do aparato (Figura 1).

A três réguas estavam dispostas da seguinte maneira: duas réguas encontra- tance in detecting and diagnosing previously several locomotors clinical problems; however the anthropometry clinical methods till now, show figures ranging from 0 to $45^{\circ}$, which is doubtful $(2,10,13,15)$.

On the other hand the tibial torsion by simple radiography is complex and unpractical/(5,7,13)

As a solution, the computerized tomography assessment has shown to be an efficient method; however have some disadvantages such as, lack of pattern and high cost which raise difficulties to the patient continues the treatment in many cases.

An anthropometry clinical device shows the figure of a leg torsion angle in an indirect way, with trigonometric accounts. The main purpose is to contribute with the leg torsion angle assessment using a simple method, easily reproduced, facilitating, then the patient treatment.

\section{MATERIAL AND METHODS}

This device consists in a mechanical apparatus which assess variable anthropometry in the frontal and sagittal leg planes determining indirectly the torsion angle. This device was made with low cost and easily availability such as : acrylic plates, three measurement rulers type glue, a wooden plaque and a few screws.

The anatomical pieces assessed belonged to the Laboratory of Anatomy of the Descriptive and Topographic Anatomy Discipline of the Morphological Department of The Federal University of São Paulo/ Paulista Medical School. This research project was approved by The Ethical and Research Committee from the same institution following the resolution of 196/96 National Healthy Institution

The 40 lower limbs studied were disarticulated of their adult human cadavers and fixed with formaldehyde. Twenty five limbs were disarticulated from the femo-

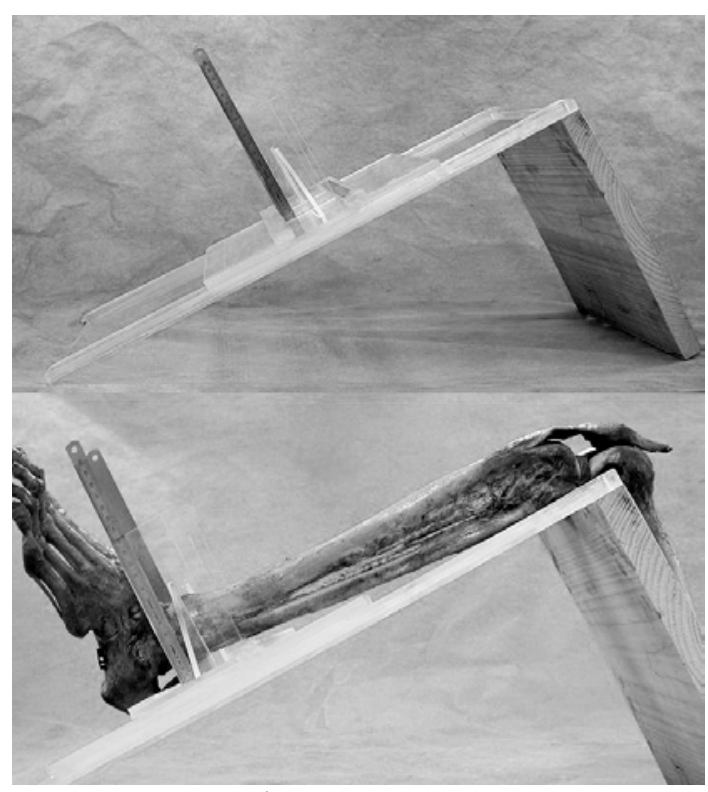

Figura 1- Acima, visão lateral do aparato, abaixo membro inferior posicionado para aferição, notar o conjunto de réguas na extremidade distal

Figure 1 - Above, the apparatus side view, below the lower limb placed to the gauging, look at the set of measurement rulers type at the distal extremity ral on, the other fifteen from the hemi pelvis on. The assessed part was not considered in the results.

The anthropometrical varieties studies were, 1- the intermalleolus distance, measuring the distance between the center of the medial and lateral malleolus (D): 2- The distance between the center of medial malleolus and the back shield of the device (M); 3- the distance between the center of lateral malleolus and the back of the shield device $(L)$

The assembling of the device consist in, 1- a principal shield support to the back part of the leg, 2another smaller wooden shield, orthogonally joined to the proximal extremity of the first one, supporting the thigh; 3- three rulers suited to the distal extremity of the main shield. In this assembling, the lower limbs researched were placed with the knee at 90 degree and the condyle of tibia and calcaneal plantar face resting on the main shie/d of the device (Figure 1). 
vam-se posicionadas no plano sagital, eram móveis e como ficavam perpendiculares ao eixo longitudinal da perna, bloqueavam sua rotação quando levadas de encontro aos maléolos; uma terceira régua permaneceu orientada no plano frontal completando o conjunto (Figura 2). A unidade das réguas era expressa em centímetros lineares apresentando precisão até um dígito decimal à direita.

O par de réguas sagitais além de ter mobilidade latero-medial, conjuntamente a terceira régua apresentavam mobilidade crânio-caudal sobre o anteparo longitudinal de acrílico.

Concluindo, a disposição dos anteparos e a mobilidade do conjunto de réguas permitiram avaliarem-se membros inferiores não importando o comprimento, a largura e o lado estudado.

A partir de pontos de referência demarcados no centro dos maléolos, mensuramos as distâncias entre os mesmos no plano frontal (D), com a leitura direta na régua fixada no anteparo posterior. Também, pela leitura nas réguas orientadas no plano sagital avaliaram-se as distâncias entre o maléolo lateral $(L)$ e medial $(M)$ em relação ao anteparo posterior. Com a obtenção das medidas acima, através do cálculo do arco tangente (1) foi obtido o valor do ângulo de torção da perna (Quadro 1)

\section{RESULTADOS}

De uma amostra de 40 membros inferiores estudados foram obtidos valores angulares entre 18 e 27 graus (Tabela 1).

Foi encontrada a seguinte distribuição, 15 membros inferiores apresentaram ângulos de torção da perna entre $20^{\circ}$ e $22^{\circ}$, representando $37,5 \%$ da amostra.
The three measurement rulers type were set as the following: two rules were placed in the sagittal plane, movable, as they were perpendicular to the longitudinal leg axis, stopped the rotation when taken towards the malleolus; a third ruler remained guided at the frontal plane completing the set (Figure 2). The rulers had linear centimeters and accurate measurement till a decimal digit at the right.

The pair of sagittal rulers, besides having lateral-medial mobility, concurrently the third ruler had head-tail mobility on the longitudinal acrylic shield.

Finally, the shield availability and the mobility of the rulers set enabled to assess lower limbs independent of the length width and the studied side.

From the references spotted on the center of the malleolus, the distance between them at the frontal plane (D), with the direct reading at the ruler fixed at the back shield. Also, by the reading at the orientated rulers at the assessed plane, the distances between the lateral malleolus $(L)$ and medial $(M)$ in relation of the back shield were assessed. With the measurement cited above, the tangent arc account (1) the figure of the leg torsion angle were obtained (Picture 1).

\section{RESULTS}

On a 40 samples of lower limbs the following figures angles between 18 and 27 degrees were obtained (Table 1).

The following distribution was found: 15 lower limbs had leg

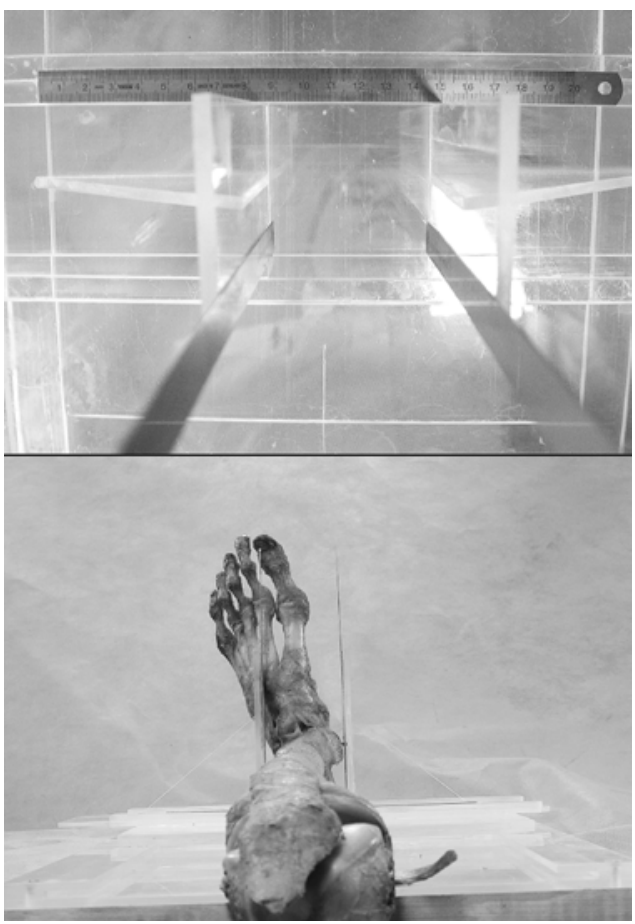

Figura 2 - Visão coronal do conjunto de três réguas, abaixo visão axial do aparato onde observamos um membro inferior já posicionado para aferição.

Figure 2 - The coronal view of the three measurement rulers type, below the apparatus axial view where the lower limb already placed to the gauging was seen

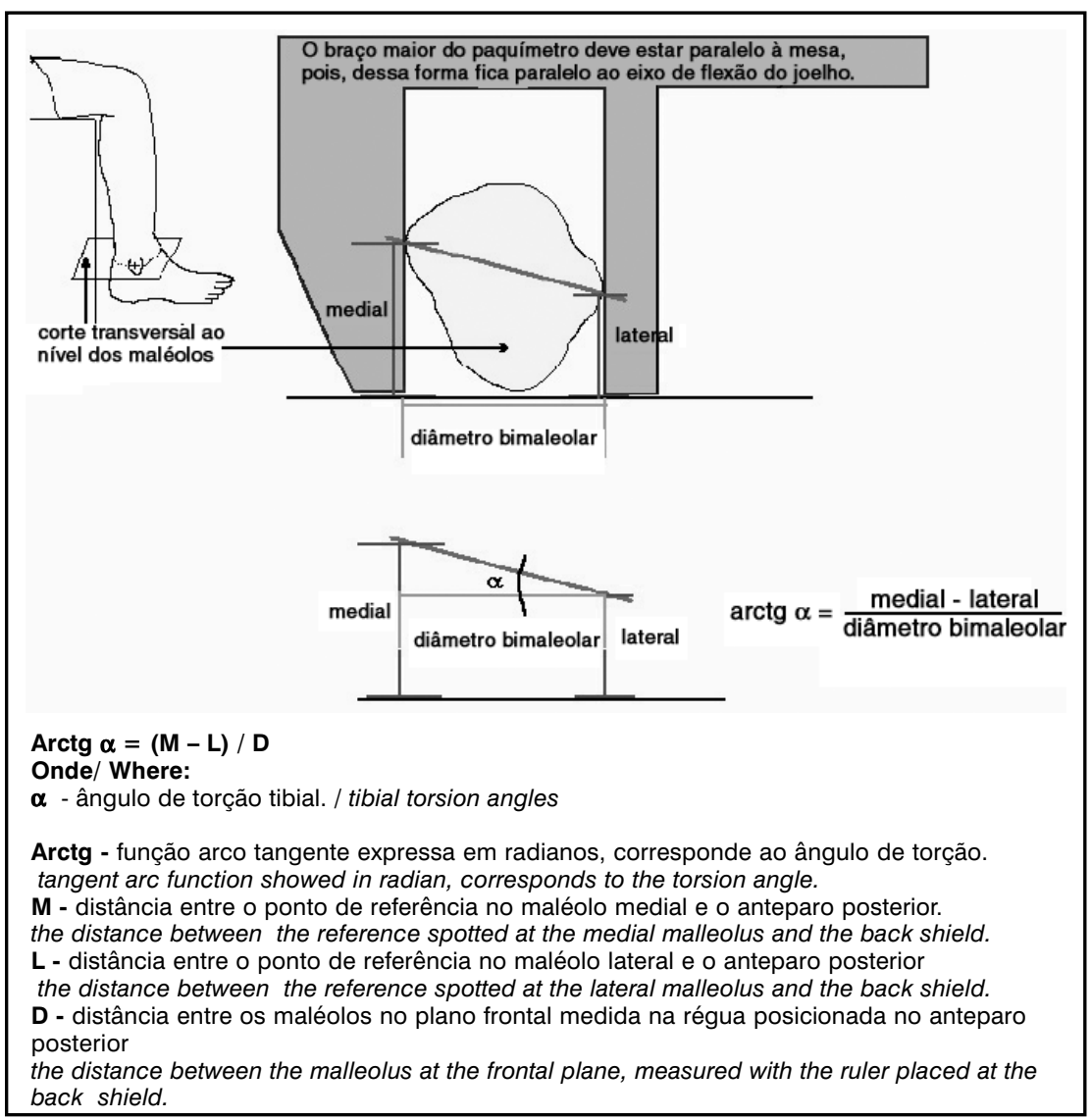

Quadro1 - Definição do arco tangente da variável angular procurada Picture 1 - Definition of the tangent arc the searched variable angle 
A média dos valores angulares de torção da perna foi equivalente $22,4^{\circ} \mathrm{com}$ um desvio-padrão $=2,2^{\circ}$ (Tabela 2 ). A variabilidade entre os valores foi relativamente pequena (coeficiente de variação $=0,099$ )

O gráfico Box-plot e o Histograma foram comparados e mostram os percentis de distribuição por concentração e frequência (Gráfico 1).

Como os valores correspondiam á medidas angulares foi utilizado também um método estatístico específico para disposição de dados circulares (Gráfico 2). A média circular, que representa o ângulo médio, coincidiu com a média descritiva $\left(22,4^{\circ}\right)$ e a variância circular amostral, valor que corresponde a uma medida de variabilidade em torno do ângulo médio, foi igual a 0,001 confirmando a homogeneidade da amostra.

\section{DISCUSSÃO}

O ser humano apresenta características biomecânicas únicas, essas características destacam-se ainda mais quando são comparados indivíduos da mesma espécie ${ }^{(9,13,14)}$.

Várias são as causas dessas alterações, cada um de nós apresenta alguma variação no eixo de

\begin{tabular}{|rccc|}
\hline M.I. & ângulo & $\mathbf{M} . \mathbf{I}$ & ângulo \\
\hline $\boldsymbol{L} \boldsymbol{L}$ & angle & $\mathbf{L L}$ & angle \\
\hline & & & \\
\hline 1 & 20,66 & 21 & 24,78 \\
\hline 2 & 20,90 & 22 & 22,25 \\
\hline 3 & 20,56 & 23 & 19,29 \\
\hline 4 & 19,36 & 24 & 19,44 \\
\hline 5 & 25,71 & 25 & 21,48 \\
\hline 6 & 20,66 & 26 & 19,21 \\
\hline 7 & 24,30 & 27 & 26,57 \\
\hline 8 & 21,80 & 28 & 23,09 \\
\hline 9 & 22,43 & 29 & 25,35 \\
\hline 10 & 21,10 & 30 & 24,04 \\
\hline 11 & 21,96 & 31 & 21,10 \\
\hline 12 & 21,66 & 32 & 24,78 \\
\hline 13 & 23,59 & 33 & 26,57 \\
\hline 14 & 22,96 & 34 & 23,50 \\
\hline 15 & 21,80 & 35 & 22,34 \\
\hline 16 & 20,56 & 36 & 27,35 \\
\hline 17 & 20,66 & 37 & 24,38 \\
\hline 18 & 21,52 & 38 & 22,75 \\
\hline 19 & 23,63 & 39 & 23,53 \\
\hline 20 & 17,68 & 40 & 21,16 \\
\hline
\end{tabular}

Tabela 1 - Ângulos de torção da tíbia obtidos de 40 membros inferiores (M.I.) de cadáveres

Table 1 - The leg torsion angle obtained in 40 lower limbs (LL) of human cadavers torsion angles between 20 degrees and 22 degrees, showed $37,5 \%$ of the sample.

The figures average of the leg torsion angle was $22,4^{\circ}$, with a standard deviation $=2,2^{\circ}$ (Table 2). The variability of the figures was relatively small (the variation factor $=0,099$ )

The Box-plot and the histogram were compared and showed the percents of the distribution for concentration and frequency (Graph 1)

As the figures corresponded to angular measurement, a specific statistics method was used for the circular data (Graph 2). The circular average which represents the medium angle, suited to the descriptive average $\left(22,4^{\circ}\right)$ and circular variation sample, the figure that corresponds to a variability of an average about the medium angle, was the same to 0,001 confirming the sample homogeneity

\begin{tabular}{|l|c|c|c|c|c|c|c|}
\hline $\begin{array}{l}\text { Ângulo de Torção Tibial (em graus) } \\
\text { Tibial torsion angle(in degrees) }\end{array}$ & $\begin{array}{c}\text { Média } \\
\text { Average }\end{array}$ & $\begin{array}{c}\text { Mediana } \\
\text { Average }\end{array}$ & $\begin{array}{c}\text { Desvio Padrão } \\
\text { Standard Deviation }\end{array}$ & $\begin{array}{c}\text { Erro Padrão } \\
\text { Standard Error }\end{array}$ & $\begin{array}{c}\text { Mínimo } \\
\text { Minimum }\end{array}$ & $\begin{array}{c}\text { Máximo } \\
\text { Maximum }\end{array}$ & $\mathrm{N}$ \\
\hline & 22,41 & 22,10 & 2,22 &, 35 & 17,68 & 27,35 & 40,00 \\
\hline
\end{tabular}

Tabela 2 - Estatísticas descritivas da amostra

Table 2 - Descriptive statistics sample

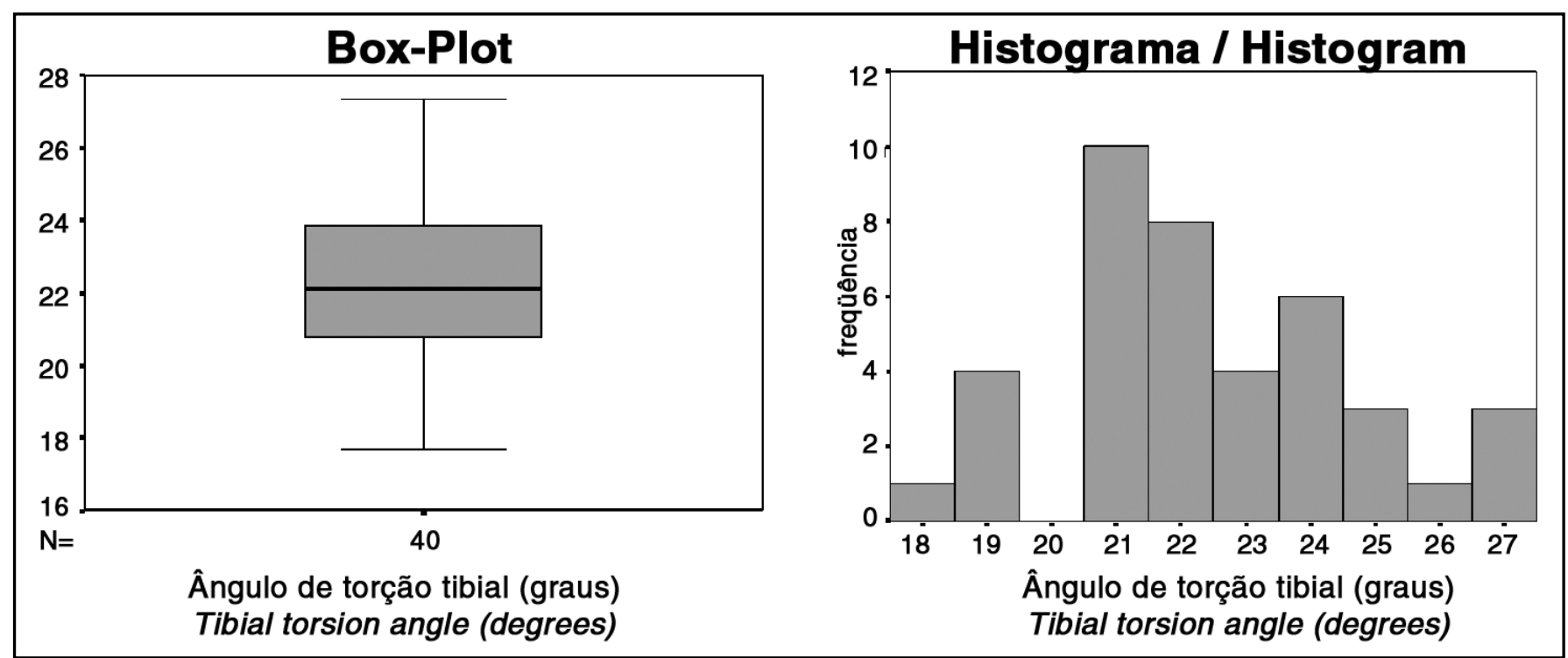

Gráfico 1 - Distribuição gráfica dos ângulos de torção da perna.

Graph 1 - Graphic distribution of the leg torsion angles. 
movimento das articulações e na rotação dos membros inferiores que podem ser temporários ou definitivos. As alterações temporárias expressam-se durante as diversas fases do desenvolvimento e as definitivas na vida adulta ${ }^{(4,9,10)}$

A postura e moldagem intra-uterinas afetam o alinhamento rotacional dos membros inferiores. No feto os quadris estão fletidos e rodados lateralmente o que implica que os quadris possuem maior grau de rotação lateral do que medial enquanto as pernas e os pés encontram-se rodados medialmente e aduzidos $(4,6,8,10)$

Ao nascimento esta postura está presente em grau variável. Durante o crescimento longitudinal, forças de tração muscular e ligamentar assim como forças estáticas do peso corporal levam á resolução espontânea e gradual da postura fetal ${ }^{(3,8,13)}$.

Os eixos de rotação da coxa e perna estão intimamente relacionados com a rotação do quadril e por conseguinte, a rotação da perna e o movimento do pé também estão em concordância.

Os eixos de rotação mostram diferenças marcantes e constituem-se num dos fatores que distinguem a aparência de cada indivíduo durante a marcha ${ }^{(4)}$.

Procurando avaliar os problemas torcionais de forma mais precisa, Staheli et al. ${ }^{(10)}$ propuseram o estudo do perfil torcional. O objetivo deste estudo foi o de fornecer valores mais precisos, para isso estudaram 1000 membros inferiores normais em crianças e adultos sendo 221 do sexo masculino e 279 do sexo feminino e estabeleceram valores normais dos perfis torcionais e rotacionais nas diversas faixas etárias.

O perfil torcional proposto no artigo consiste na mensuração de seis parâmetros de cada membro inferior do indivíduo, a saber: 1- o ângulo de progressão do pé; 2- a rotação medial do quadril em extensão; 3- a rotação lateral do quadril em extensão; 4- o ângulo coxa-pé; 5- o ângulo do eixo transmaleolar; 6- a configuração do pé.

O valor do ângulo do eixo transmaleolar é obtido com o paciente em pronação, os joelhos fletidos a $90^{\circ} \mathrm{com}$ os tornozelos na posição neutra. São marcados pontos centrais dos maléolos medial e lateral e unidos por uma linha através da planta do pé representando o eixo transmaleolar. A seguir, uma linha é projetada no sentido longitudinal do calcanhar e perpendicular ao eixo transmaleolar. O ângulo do eixo transmaleolar é portanto a diferença angular entre esta linha projetada no maior eixo do calcanhar e o eixo da coxa.

Em última análise podemos concluir que o eixo transmaleolar estaria avaliando a torção tibial e que o ângulo do eixo transmaleolar aumenta conforme a idade tendo um valor médio aproximado na infância de $20^{\circ}$ podendo variar de $0^{\circ}$ a $45^{\circ}(4,10)$.

Staheli et al (10) concluíram em seu artigo que, para finalidades práticas nos casos de problemas torcionais simples devem ser utilizados os valores obtidos pela aferição do ângulo coxa-pé uma vez que este método fornece dados semelhantes e paralelos aos obtidos pela técnica de avaliação do eixo transmaleolar ${ }^{(4,10)}$ porém, o ângulo coxa-pé é uma avaliação da deformidade combinada da rotação da tíbia e do retropé.

Tendo em vista as técnicas descritas acima, concluímos que na prática não há um método antropométrico simples que avalie a torção apenas com parâmetros da perna e que forneça também dados mais constantes.

\section{DISCUSSION}

The human beings show unique biomechanical characteristics, and these characteristics are more evident if compared to the same individuals spe$\operatorname{cies}^{(9,13,14)}$.

There are several possible causes of these alterations, each of us has some variation in the articulation movement axis and the lower limbs rotation which may be temporary or definitive. The temporary ones appear during several development phases and the definitive ones in the adult life ${ }^{(4,9,10)}$.

The posture and moulding inter-uterine affect the lower limbs rotational alignment. In the fetus the hips are flexed and rotated laterally which shows the hips have bigger lateral degree rotation than the medial ones while the legs and feet are medially rotated and brought forward $(4,6,8,10)$.

At the birth this posture is presented in variable degree. During the longitudinal growing, traction and muscular strength alignment as well as the static strength of body weight lead to the spontaneous and gradual resolution of the fetus posture ${ }^{(3,8,13)}$.

The thigh and leg axis rotation are linked to the hips rotation, therefore, the leg rotation and the feet movement are in accordance.

The axis rotation shows remarkable differences and it is one of the factors which distinguish each individual appearance during the bait while marching ${ }^{(4)}$.

In order to assess the torsion problems more accurately, Staheli et al. ${ }^{(10)}$ suggested the torsion profile study. The purpose of it is to supply more accurate figures, therefore 1000 normal lower limbs of children and adults, 221 of male and 279 female and established normal figures of the torsion and rotation profile of different ages.

The proposed torsion profile in this article consists in measuring six parameters of each lower limb individually, to know: 1the feet progression angle; 2- the extension hips medial rotation; 3- the extension of the lateral hip rotation; 4-the-feet -leg angle; 5- the transmalleolus angle axis; 6- the foot configuration.

The obtained figure of the transmalleolus angle axis is given when the patient is in pronation, the knees flexed at $90^{\circ}$ with the ankles in neutral position. Central spots in the medial and lateral malleolus are made and joined with a line on the feet plantar showing the transmalleolus axis. Then a line is projected in the longitudinal direction of the heel being perpendicular to the transmalleolus axis. The transmalleolus angle axis is the angular difference between this projected line in the largest heel axis and the thigh axis.

Ultimately the transmalleolus axis would be assessed the tibial torsion and the transmalleolus axis increasing according to the age with a medium figure of $20^{\circ}$ in the childhood may vary between $0^{\circ}$ to $45^{\circ(4,10)}$.

Staheli et al. ${ }^{(10)}$, concluded in their article, to practical objectives in case of the simple torsion problems it must be used the obtained figures by the gauge of thigh-feet angle as this method 
A biomecânica do aparelho locomotor humano é complexa e consiste num intrincado mecanismo que funciona de maneira interdependente entre as partes. Cada parte tem importância e contribuição ímpar, a perda ou modificação de um componente pode resultar em grandes ou pequenas alterações. A única forma de entendê-las é compreendendo como cada componente está distribuído no indivíduo ${ }^{(4)}$ assim como, é vital a compreensão das alterações biomecânicas que cada doença provoca no aparelho locomotor $(1,3,6,8,11)$.

A compreensão da biomecânica do membro inferior é auxílio essencial, para tomada de decisão do cirurgião e implica no planejamento cirúrgico e conseqüentemente no sucesso pós - operatório ${ }^{(4,5,13)}$

Sabemos que o grau de torção da perna depende da idade da criança e é variável entre indivíduos. A evolução natural da torção da perna é a tendência a rodar lateralmente com a progressão da idade.

LeDamany em 1909 foi um dos pioneiros na avaliação da torção tibial em espécime anatômicos $(4,5,7,10)$. O autor descreveu que no feto o maléolo medial localiza-se atrás do lateral e que há torção medial na tíbia. Ao nascimento, as extremidades dos maléolos estavam niveladas e pela época da marcha o maléolo medial encontra-se situado á frente do maléolo lateral e que havia por volta de $20^{\circ}$ de torção tibial. O autor ainda encontrou no indivíduo adulto normal a torção tibial lateral com uma média de $23,7^{\circ}(2,4,7)$

Staheli e Engel ${ }^{(9)}$, estudaram o grau de torção tibial em 160 crianças normais e adultos através de um aparato que determinava o valor do eixo transmaleolar com o joelho a $90^{\circ}$. Os autores observaram que a torção aumentava com a idade, ocorrendo durante o primeiro ano de vida aumento de $5^{\circ}$ na rotação lateral, $10^{\circ}$ nas crianças mais veIhas, e $20^{\circ}$ nos adultos. O método é pouco detalhado no artigo e aparentemente foi abandonado pelo autor no seu artigo mais recente de $1985^{(10)}$

O dispositivo apresentado por nós pode ser considerado como um aprimoramento do que fora apresentado por Staheli e Engel ${ }^{(9)}$, acrescenta-se à defesa do método além do que já exposto, o fato que métodos radiográficos não podem ser aplicados aos lactentes ou crianças pequenas, em virtude da ausência de sombras de contraste projetadas pelas suas epífises cartilaginosas.

A avaliação radiográfica da torção tibial não é indicada em crianças tendo limitado valor clínico e a exposição à radiação não é justificável $(2,4,7,12)$

Ao confrontarmos o método proposto com a técnica de avaliação da torção tibial por tomografia computadorizada temos que, o custo mais elevado deste último é um dos pontos mais desfavoráveis prejudicando o seguimento, a radiação ainda que menor em relação ás radiografias simples também deve ser citada como ponto negativo $(7,13)$

O valor médio de torção tibial num adulto normal obtido através de tomografia pode variar de $30^{\circ}$ para lateral com desvio-padrão de até $5^{\circ}(5,12,13)$. Porém os valores variam ainda mais conforme o estudo ${ }^{(7)}$ um dos motivos apontados para a inconstância é que há uma dificuldade de padronização das linhas de referência distal e proximal na tíbia $(5,7,15)$

\section{CONCLUSÃO}

Considerando-se os estudos com diversos aparatos mecânicos citados na literatura, os resultados apresentados neste artigo encontram-se numa faixa aceitável para o indivíduo adulto normal porém outros estudos deverão seguir-se.

O método proposto neste artigo para a avaliação do ângulo de torção da tíbia tem vantagens dentre as quais: 1 - é um equipamento barato confeccionado com materiais facilmente acessíveis; 2- o uso é supplies similar and parallel data obtained by the transmaleolus evaluation technique ${ }^{(4,10)}$; however, the thigh-foot angle is a combined deformity assessment of the tibial rotation and the retrofeet.

Analyzing the techniques cited above, it does not exist a simple anthropometry which assess only with the leg parameter torsion and supply more constant data.

The biomechanical of the human locomotor is complex and a difficult mechanism which works in interdependent way among the parts. Each part has unique importance and contribution, the loss or change of a component can result into important or small alterations. The only way to understand them is analyzing how each component is distributed in the individual(4), as well as the importance to understand the biomechanical alterations that each clinical problems cause in the locomotor parts ${ }^{(1,3,6,8,11)}$.

The understanding of the biochemical lower limb is an essential support to the surgeon decision and it implies in the surgical plan and consequently in the post-operatory suc$\operatorname{cess}^{(4,15,13)}$.

It is known the leg torsion degree depends on the child age and it is variable in adults. The natural evolution of the leg torsion is to rotate laterally with the age.

In 1909 LeDemany was one of the first to assess the tibial torsion in anatomical specimen ${ }^{(4,5,7,10)}$. He described that in the fetus the medial malleolus is located behind the lateral one and there is medial tibial torsion. At the birth, the malleolus extremities were flatted and for the bait time the medial malleolus was in front of the lateral malleolus and there was around $20^{\circ}$ tibial torsion. He also found a normal adult individual with normal lateral tibial torsion with the average of $23,7^{0}(2,4,7)$.

Staheli and Engel (9), studied the tibial torsion degree in 160 normal children and adults with a device which determined the figure of the transmalleolus axis with the knee at $90^{\circ}$. They observed that the torsion increases according to the age, occurring at the first year of life increased $5^{\circ}$ lateral rotation, $10^{\circ}$ in older children, and $20^{\circ}$ in adults. This method had few details and it seems to have been put aside by the author in his more recent article of $1985^{(10)}$

The device presented can be considered as improvement of what was showed by Staheli and Engel( ${ }^{(9)}$, besides what has been presented, it is added the fact of the radiographic methods can not be used with babies or small children due to the lack of shadow contrast projected for its cartilaginous epiphyses.

The radiographic assessment of the tibial torsion is not suggested with children having limited clinical value and the exposition to radiation is not an argument $t^{(2,4,7,12)}$

Confronting the proposed method with the torsion assessment technique using computerized tomography, we have to consider the high cost of it, which is a weak point to follow the treatment, even being a smaller radiation if compared to a simple radiography it also has to be classified as a negative point ${ }^{(7,13)}$

The medium figure of a tibial torsion in a normal adult obtained with the tomography can vary of $30^{\circ}$ to the lateral with a standard deviation till $5^{\circ(5,12,13)}$. However the figures vary even more according to the study (7). One of the reasons of the inconstancy is the difficulty of standardize the distal and proximal tibia referent line ${ }^{(5,7,15)}$. 
descomplicado e portanto requer pouco treino tanto para profissionais médicos como não médicos; 3- o método é pouco agressivo e torna-se conveniente para seguimento ambulatorial; 4- os valores obtidos são compatíveis com os da literatura.

\section{AGRADECIMENTOS}

Ângela Tavares Paes, Mestre em Estatística do Laboratório de Epidemiologia e Estatística (Lee) do Instituto Dante Pazzanese de Cardiologia.

\section{CONCLUSION}

Considering the several mechanical devices studies cited in the literature, the outcomes showed in this article to be suited in acceptable level for a normal individual, however other studies must be continued.

The proposed method of this article for the tibial torsion angle assessment has some advantages, such as , 1- it is a cheap equipment made of easily available material;2- the use is not complicated therefore a little training for physicians or no physicians is need; 3- the method is not so severe, consequently convenient to the laboratorial following; 4- the figures obtained are compatible with the ones in the literature.

\section{ACKNOWLEDGEMENTS}

Ângela Tavares Paes, Statistics Master at the Epidemiology and Statistics Laboratory (ESL) of the Dante Pazzanese Cardiology Institute.

\section{REFERÊNCIAS BIBLIOGRÁFICAS}

1. Cameron JC, Saha S. External tibial torsion: an underrecognized cause of recurrent patellar dislocation. Clin Orthop 328:177-184, 1996.

2. Clementz BG. Assessment of tibial torsion and rotational deformity with a new fluoroscopic technique. Clin Orthop 245:199-209, 1989

3. De Alba CC, Guile JT, Bowen JR, Harckle HT. Computed tomography for femoral and tibial torsion in children with clubfoot. Clin Orthop 353:203-209, 1998.

4. Inman VT. Introduction. In: Inman VT, Ralston HJ, Todd F. Human Walking. Baltimore: Willians \& Wilkins, 1981. p.15-21

5. Jend $\mathrm{HH}$, Heller M, Dallek M, Schoettle H. Measurement of tibial torsion by computer tomography. Acta Radiol Diag 22:271-276, 1981

6. O'Connell AP, D'Souza L, Dudeney S, Stephens M. Foot deformities in children with cerebral palsy. J Pediatr Orthop 18:743-747, 1998.

7. Reikeras $\mathrm{O}$, Hoiseth A. Torsion of the leg determined by computed tomography Acta Orthop Scand 60:330-333, 1989.

8. Reikeras $\mathrm{O}$, Kristiansen LP, Gunderson $\mathrm{R}$, Steen $\mathrm{H}$. Reduced tibial torsion in congenital clubfoot: CT measurements in 24 pacients. Acta Orthop Scand 72:53-56, 2001.
9. Staheli LT, Engel GM. Tibial Torsion: a method of assessment and a survey of normal children. Clin Orthop 86:183-186, 1972

10. Staheli LT, Corbett M, Wyss C. Lower extremity rotational problems in children: normal values to guide management. J Bone Joint Surg Am 67:39-47, 1985

11. Stanitski CL, Christopher SL, Deborah FS. Tibial torsion in chronic, stable slipped capital femoral epiphyses: Evaluation by CT scan. J Pediatr Orthop $17: 657-658,1997$

12. Stuberg W, Temme JL, Kaplan P, Clarke A, Fuchs R. Measurement of tibia torsion and thigh-foot angle using goniometry and computed tomography. Clin Orthop 272:208-212, 1991.

13. Tachdjian MO. O pé e a perna. In: Ortopedia Pediátrica. $2^{a}$ ed. São Paulo: Manole, 1995.p.2826-2833. [1 ${ }^{\text {a }}$ tradução brasileira]

14. Weinstein SL. The Pediatric Foot. In: Weinstein SL, Buckwalter JA. Turek's Orthopaedics: Principles and their Application. $5^{\text {th }}$ ed. Philadelphia: J.B. Lippincott Company, 1994. p.646-650

15. Yagi T, Sasaki T: Tibial torsion in patients with medial type osteoarthritic knee Clin Orthop 213:177-182, 1986. 